\author{
Britt W. Svenhard \\ Høgskolen i Østfold, Halden
}

DOI: http://dx.doi.org/10.5617/adno.5645

\title{
Å lese film
}

\section{Sammendrag}

Mange larere ønsker å bruke film i engelskundervisningen, men ser kanskje ikke umiddelbart hvordan dette kan forankres i lcereplanmål eller hvilke arbeidsmåter man kan velge. Denne artikkelen ser på hvordan Kunnskapsløftet (2017) åpner for mer bruk av film og hvilke muligheter som ligger $i$ å se elevenes forkunnskaper om visuelle tekster og sjangre som bidrag i byggingen av literacy-kompetanse. Det vises til forskning og utviklingsarbeid innen kunstfagene som fremholder viktigheten av at elever får utvikle språk til å fortelle historier basert på visuelle inntrykk (Bamford, 2008; Yenawine, 2014). Det beskrives videre hvordan lerere kan overføre lesestrategier fra disse fagene til engelskundervisningen for å gi elevene bedre rammer for å forstå og bruke film og andre visuelle narrative tekster i en språkfaglig sammenheng. Artikkelen ser ncermere på hvordan sjangerlæere (Mjør et. al., 2006; Stafford, 2011) kan vcre et møtepunkt mellom film og skjønnlitteratur. A integrere film bedre $i$ engelskfaget kan også bidra til å styrke elevenes metakognitive kompetanse. Metodene som beskrives illustrerer hvordan visuelle tekster og kunnskap om leringsstrategier og forståelse for egne lceringsprosesser i møte med slike tekster kan utløse mer kritisk tenkning og selvstendig læring.

Nøkkelord: film, literacy, lesestrategier, sjangerlæere, eventyr, fantasy, kritisk tenkning.

\section{Reading films}

\begin{abstract}
This article addresses teachers who are looking to integrate film into their English syllabus and who are searching for related methods that will enable them to fulfil both subject and core curriculum aims (Kunnskapsløftet 2017). I explore methods and approaches for the utilization of Norwegian students' extensive knowledge of visual texts and genres in the teaching of literacy and metacognitive competence. The discussion draws on research and teaching practices that demonstrate how arts integration into other subjects facilitates student output and metacognitive and higher order thinking (Bamford, 2008;
\end{abstract}


Yenawine, 2014). My emphasis is on the combined use of reading comprehension and visual thinking strategies in the teaching of film in EFL courses and I propose genre-based teaching (Mjør et al., 2006; Stafford, 2011) as a viable approach to a more comprehensive literacy instruction, including both literary and film narratives. I also look at how encouraging the transfer of students' prior knowledge of film and narrative patterns can contribute to greater learner autonomy.

Keywords: film, literacy, reading strategies, visual thinking strategies, genrebased teaching, critical thinking.

We should ... continuously give kids the chance to use and widen their capacity to learn on their own. If we don't, we end up with adults who feel as if they need help understanding something well within their reach. (Yenawine, 2014, s. 14)

\section{Utgangspunkt}

Kunnskapsløftet åpner for bruk av et bredt utvalg av tekster, inkludert film. Læreplanen i engelsk sier blant annet at elevene skal «gi uttrykk for egne tanker og meninger i møte med engelskspråklig litteratur og barnekultur» (etter 4. årstrinn) og «gi uttrykk for egne reaksjoner på engelskspråklige litterære tekster, film, nettkultur, bilder og musikk» (etter 7. årstrinn) (Kunnskapsdepartementet, 2017, s. 58-59).

Bakken (2016) har undersøkt ungdomsskolelæreres diskurs om læringsverdien av film i engelskundervisningen og fant blant annet at lærernes antakelser handlet vel så mye om deltakelse og demokrati som om språklæring. Bakken konkluderer med at lærerne anser film både som et godt verktøy for å kompensere for variasjoner i elevenes språkkompetanse og som mediering mellom eldre skjønnlitterære tekster og elevenes egne teksterfaringer. Film fremheves allikevel sjelden som en selvstendig ressurs i engelskundervisningen, og måten lærerne bruker filmtekster på, ser her ut til å reflektere læreplanens definisjoner av film som «inspirasjon» og «kulturuttrykk», noe Bakken mener er uklare definisjoner av filmers funksjon i undervisningen (Bakken, 2016, s. 4). Bakkens funn gjelder ungdomstrinnet, men jeg mener de belyser viktige sider ved læreres praksisteori som er overførbart også til mellomtrinnet, som jeg tar for meg i denne artikkelen.

Her drøfter jeg hvordan arbeid med film og lesekompetanse i engelskfaget kan få bedre vilkår gjennom en kunstfaglig tilnærming og hvordan elevenes metakognitive kompetanse kan styrkes gjennom bruk av visuelle lesestrategier. Artikkelen er todelt. I første del tar jeg for meg literacy-begrepet, læreres antagelser om filmers læringsverdi, mulige effekter av kunstfaglig tilnærming og 
hvordan visuelle lesestrategier kan bidra til å øke elevers selvtillit og mulighet til å delta i undervisningen. Videre beskriver jeg hvordan sjangerlære kan være en måte å integrere filmtekster på, i arbeidet med lesekompetanse i engelskfaget. I del to gir jeg et konkret eksempel på hvordan noen av de teoretiske problemstillingene kan løftes inn i undervisningen på mellomtrinnet gjennom bruk av Disney-Pixar-filmen Brave (2012).

Når det gjelder eksplisitt arbeid med metakognisjon i språkundervisningen, spiller dette en viktig, men allikevel underordnet rolle i denne artikkelen, i forhold til fokuset på tilrettelegging for elevens respons, refleksjon og språkproduksjon knyttet til film som fiksjonstekst og kunstuttrykk. Flavells (1979) modell for metakognisjon, slik den for eksempel blir forklart av Iwai (2011), ligger ofte til grunn for undervisning i læringsstrategier i språkfagene og reflekteres i denne artikkelen i forbindelse med beskrivelser av læringsaktiviteter for utvikling av vokabular og begrepsforståelse i undervisning basert på Brave. Her nevnes også ulike førlesningsaktiviteter som aktiverer forkunnskaper og som forbereder elevene på innholdet i en tekst, og etterlesningsoppgaver for bearbeidelse av informasjon. Dette er utbredte leseteknikker for å lære elevene hvilke verktøy de kan benytte for å øke forståelsen av innhold og budskap i en tekst. Fokuset i denne artikkelen ligger imidlertid mindre på forståelse av budskap og kontroll, overvåking og regulering av egen læring, og mer på hvordan vi kan gi alle elever muligheter til å gi uttrykk for egne opplevelser, reaksjoner og meninger i møte med fiksjonstekster, slik at de blir i stand til å lære på en mer selvstendig måte. Spesielt drøftes Yenawines (2014) strategier for arbeid med visuelle tekster. Noen av læringsstrategiene som omtales i artikkelen må derfor mer sees som ledd i å forberede elevene språklig, slik at de kan uttrykke seg (muntlig og skriftlig), slik fagplanen krever, om egne reaksjoner og meninger og dermed kunne delta i diskusjoner. De visuelle lesestrategiene som beskrives bidrar mer direkte til refleksjon, kritisk tenkning og meningsdanning - mer i tråd med overordnet del i læreplanen. Ved å se film ikke kun som fiksjonstekst på linje med skjønnlitteratur i engelskfaget, men også som kunstuttrykk, åpnes det opp for flere tilnærmingsmåter i undervisningen som igjen gjør det mulig å arbeide med flere av de overordnede målene. Dette kan av og til være et nyttig perspektiv å ta i engelskundervisningen, spesielt i perioder hvor lærere ønsker å arbeide mer med elevenes forforståelse og deres egne meninger, refleksjoner og kritiske tenkning knyttet til kunst- og kulturuttrykk og vil se dette omsatt og synliggjort i elevenes muntlige og skriftlige produksjon.

\section{Lesekompetanse (literacy)}

Definisjonen av lesekompetanse (literacy) har lenge vært knyttet til lesing og tolkning av skriftlige tekster og evnen til å kunne ta i bruk skriftspråket for å 
fungere og ta seg frem i samfunnet. I den senere tid har begreper som multiple literacies og new literacies blitt introdusert, dels for å utvide tekstbegrepet til å inkludere visuelle og multi-modale tekster som film og andre medier, men også for å tilby en mer dynamisk definisjon som tar høyde for utviklingen innen digital kompetanse og kommunikasjon (Cole \& Pullen, 2010; Lankshear \& Knobel, 2011). Vi ser også at literacy-begrepet blir brukt på måter som omfatter flere grunnleggende ferdigheter og kompetanser: 'Now when people speak of literacy, they often include listening, talking, reading, writing, viewing and critical thinking' (Makin \& Whitehead, 2004, s. 116).

At den norske skolen har fokus på og jobber godt med de tradisjonelle leseferdighetene viser den siste publiserte internasjonale leseundersøkelsen, PISA 2015, hvor norske elever fortsetter å gjøre fremskritt sammenlignet med tidligere resultater (Kjærnsli \& Jensen, 2015). Utenfor skolen må tilgangen til engelskspråklig film og andre visuelle og sammensatte tekster gjennom ulike digitale medier sies å være god for langt de fleste av våre elever. Og som Mjør, Birkeland og Risa (2006) skriver, har barn og unge en bred og variert tekstkompetanse og kjennskap til mange ulike medier og sjangre og disses uttrykksmåter og konvensjoner. Byggingen av elevenes engelskkunnskap og tekstkompetanse begynner altså ikke i første klasse. Tvert i mot kommer de til skolen med betydelig kunnskap om populærkultur og skriftlige og visuelle narrative uttrykk som eventyrfortellinger og filmer - tekster fra den engelskspråklige verden barna ofte blir kjent med først eller delvis gjennom originalspråket. I tillegg til den rike tilgangen på autentiske tekster som engelske sanger og spillefilmer og animasjonsfilmer med engelsk tale, møter barn også språket relativt hyppig i ulike medier som YouTube, Netflix og TV-kanaler rettet mot barn. I tillegg til en passiv språkkompetanse, får de også på denne måten en indirekte kunnskap om hvordan kjente fortellingsmønstre realiseres i ulike typer tekster og sjangre i populærkulturen. Forutsetningene for å jobbe med videre med literacy og ulike lese- og læringsstrategier i engelskundervisningen burde dermed være gode.

Penne (2010) påpeker imidlertid at dette er en relativt skjev eksponering av barn og unge til fordel for andre mediers narrativer enn skjønnlitteraturens. Hun viser til forskning som sier at «det er en forforståelse i bøkenes verden som er og blir forutsetningen for hvordan barn og unge kan nyttiggjøre seg andre medier» (Penne, 2010, s. 18). Elevenes lave metakognitive bevissthet om de nye medienes språk fører, i følge Penne, til et literacy-problem:

Elevene møter fiktive verdener først og fremst gjennom fjernsyn og film, og det er sannsynligvis blitt vanligere at mange elever ikke klarer å skille mellom fiktive og faktiske verdener. De har ikke tilegnet seg metaspråklige rammer for fiksjon - en form for forståelse som kan forsterke andre forståelsesformer i en komplisert medieverden. (Penne, 2010, s. 18-19) 
At undervisningen ofte mangler konkrete læringsmål for å utvikle et slikt metaspråk, bekreftes langt på vei i Bakkens intervjuer med lærerne. Filmer benyttes fordi lærernes erfaringer tilsier at de har læringsverdi, men det dokumenteres ikke på hvilken måte.

Bakken (2016, s. 2) deler lærernes antagelser om læringsverdien av film inn i fire kategorier; den referensielle, den kompensatoriske, den emosjonelle og den språklige verdien. To forhold i Bakkens analyse er særlig relevant for denne artikkelen. For det første viser Bakken at når lærere snakker om «dybdeforståelse» i forbindelse med film, ser de ut til å knytte den referensielle verdien (filmen som dokumentasjon av eller referanse til den virkelige verden) til den emosjonelle. Det vil si at filmers evne til å appellere til sanser og følelser gjør dem til egnede verktøy for å få elever engasjert i ulike temaer. Dette engasjementet sees også som del av inkludering, siden «what cannot be understood through words, can be understood emotionally» (Bakken, 2016, s. 12).

Den kompensatoriske verdien forklares av lærerne ved at den visuelle fremstillingen i en fiksjonsfilm vil kunne erstatte eller utdype og forklare abstrakt og vanskelig tilgjengelig innhold i litteraturen for svakere elever, både når det gjelder språk og tema. Når det gjelder den språklige verdien, vektlegger lærerne denne i mindre grad, og i diskursen fremstår den heller som en viktig del av den kompensatoriske, der målet er å få alle elevene til å forstå innholdet. For svake lesere kan film derfor "adapt the acquisition of advanced matters to the abilities and maturity of the reader» (Bakken, 2016, s. 12).

En mulig løsning på Pennes (2010) problemstilling, og en måte å følge opp lærernes antagelser på, er at vi tar utgangspunkt i det utvidede literacy-begrepet og leter utenfor språkfagene for å finne lesestrategier og arbeidsmåter som gir elevene både rammene Penne etterspør og overføringsmuligheter mellom kunnskapene og ferdighetene elevene kommer til skolen med og den undervisningen de får.

\section{Leseforståelse og metakognisjon i kunstfagene}

I Bamfords (2008) store kartlegging av kunstfagenes effekt og betydning i utdanning, Wow-Faktoren, understreker hun viktigheten av det mer generelle utdanningsmessige utbyttet som kunst- og kulturfagene kan gi i motsetning til det mer "positivistpregede» fokuset hun mener globale undersøkelser av utdanningsstandarder har, for eksempel på resultater elevene oppnår i matematikk, lese- og skriveferdigheter og naturfaglig tenkning (Bamford, 2008, s. 25). Hun skiller mellom utdanning i kunstfagene og utdanning gjennom kunstfagene og trekker frem resultater fra kartleggingen som viser at kunstneriske læringsaktiviteter i stor grad kan fungere som hjelpemiddel for læring av andre typer innhold. Prosjektene som beskrives i kartleggingen har 
ofte en tilnærming der «kunst brukes for å gi tilgang til begreper og meningsdannelse» (Bamford, 2008, s. 109), og ifølge Bamford viser funn fra slike prosjekter at elevers resultater og prestasjoner forbedres på flere områder, spesielt i utviklingen av muntlige, skriftlige og digitale ferdigheter. I tillegg ser man en økning i elevenes evne til analytisk vurdering av egen læring og mer uavhengig og iboende motivert investering i egen læring. Det er allikevel den kunstfaglige tilnærmingens mulighet til å bygge selvtillit hos elevene til å ta del i meningsskapende arbeid, utvikle problemløsning, kritisk tenkning og samarbeidsferdigheter som av Bamford blir trukket frem som den viktigste og mest betydningsfulle effekten. Dette fordi det også kan sees i sammenheng med utvikling av demokratiske kompetanser, dvs. «et sett av nødvendige kognitive, følelsesmessige og kommunikative ferdigheter og av relatert kunnskap for fredelig sameksistens» (Bamford, 2008, s. 118).

Bamford ser derfor kulturbasert og kunstfaglig utdanning som selve kjernen i effektiv, engasjerende og vellykket utdanning som utvikler elever med selvtillit. Denne muligheten for barn til å utfolde seg gjennom kreativitet og fantasi har tradisjonelt blitt sett på som hovedgrunnen til å inkludere kunstfag i undervisningen, men kartleggingen viser at både elever og lærere oppfatter kreativitet og fantasi «mer som undervisnings- og læringsmetoder enn som innhold. For eksempel vil en læringstilnærming basert på kunstfag gjerne være mer original, inntagende, åpen og upartisk og elevsentrert» (Bamford, 2008, s. 130), og fokus er på å lære elevene «'hvordan man kan tenke' heller enn 'hva man skal tenke'» (Bamford, 2008, s. 136). Dette henger naturlig sammen med hvordan vi i dag forholder oss til kunst, hvor «teknologiens voksende betydning [har] ført til en renessanse for interessen for kunst. Samtidens estetiske kultur går utover hva vi tidligere har kalt kunst eller kunsten. Ettersom kunstens innflytelse på kommunikasjon, teknologi og meningsdannelse øker, vil skolene våre trenge å fokusere på kunstrik utdanning som oppmuntrer til kritisk tenkning, problemløsning og refleksjon. Denne nye virkeligheten er læringens kritiske og estetiske verden» (Bamford, 2008, s. 19).

\section{Visuelle lesestrategier}

Keene og Zimmermann (2013), påpeker at noen lesestrategier som ofte brukes i arbeid med elevers tekstforståelse like gjerne kan kalles tenkestrategier (thinking strategies). Typisk for disse er at de anerkjenner elevenes egne bidrag og tilbyr dem en tilnærmingsmåte der de oppmuntres til å bruke tid på å artikulere seg, tenke høyt og utvikle tekstforståelse sammen med andre. I denne sammenhengen velger jeg å forstå lesekompetanse og lesestrategier på tilsvarende vis, som tenke- og forståelsesstrategier. Når vi her spesielt tar for oss film, kan det være nyttig med en konkretisering av hva visuell lesekompetanse består i og hva tenkestrategier kan innebære i denne sammenhengen. Giorgis et 
al. (1999, s. 146) definerer visual literacy som 'the ability to construct meanings from visual images'. Dette er en anvendelig definisjon som gir oss en vei videre for hvordan vi skal jobbe med denne typen lesekompetanse. En tilsvarende tilnærming har også Yenawine (2014), som i sin bok Visual Thinking Strategies skriver om sitt mangeårige prosjekt med bildekunst for å utvikle elevenes kritiske tenkning og kommunikative kompetanse. Her hevder han at den elevrettede undervisningen i visuelle lesestrategier bidrar både til dybdelæring, kritisk tenkning og utviklingen av språkferdighetene som skal til for å uttrykke dette og at disse ferdighetene er overførbare til og helt nødvendige i flere fag. I følge Yenawine er ikke kunnskap om å analysere tekster tilstrekkelig til at en slik overføring skal skje. Det er den visuelle kunstens og uttrykkets mulighet til å påvirke leserens følelser i kombinasjon med annen informasjon som utløser engasjement og forståelse hos leseren. Han understreker samtidig at disse visuelle leseferdighetene er noe vi alle er født med. Det er naturlig at leseren av et bilde, for å finne mening, vil prøve å skape en narrativ ut av informasjonen i bildet, og at dette ikke forutsetter at elever først har lært seg å lese skjønnlitteratur.

Yenawine (2014) legger opp til en prosess i form av diskusjoner og muntlig ferdighetstrening, der elevene svarer på spørsmålet «What is going on in this picture?», noe som oppmuntrer dem til å lete etter narrativer i tillegg til å beskrive det de ser. Deretter vil læreren prøve å få elevene til å forklare og underbygge sine individuelle tolkninger ved å stille spørsmålet: «What do you see that makes you say that?» (Yenawine, 2014, s. 26). Lærerens oppgave er å være en nøytral tilrettelegger, som ikke forventer 'riktige' svar på disse spørsmålene, men som tvert i mot oppmuntrer til undring og prøver å få frem elevenes ulike tolkninger av den visuelle teksten. Målet er at læreren skal anerkjenne elevenes interesser og bakgrunn, hjelpe dem til å gjøre mer detaljerte observasjoner, utvide sitt vokabular og utvikle et mer presist språk for å forklare hva de ser og hvordan de forstår det, uten at de opplever at de blir testet. Læreren sammenstiller og kobler de ulike tolkningene og hjelper elevene til i fellesskap å videreutvikle ulike narrativer, finne alternative tolkninger eller gjøre endringer i de opprinnelige tolkningene og trekke slutninger. Slik lærer elevene hvordan man på egenhånd og sammen med andre kan danne mening, bygge kunnskap og gjennom å dele den, oppnå mer nyansert tenkning. Ifølge Yenawine (2014) viser forskning at etter hvert som elevene blir fortrolige med denne metoden, begynner de uoppfordret å begrunne sine tolkninger med observasjoner, noe som tilsier at de har fått et metakognitivt blikk på leseprosessen. At de etter hvert begynner å bruke uttrykksmåter som relativiserer egne utsagn, eller åpner for andre tolkninger, tyder også på at de oppnår større grad av høyereordenstenking. Når det gjelder språkferdigheter, rapporterer lærere i Yenawines prosjekter, i likhet med lærere i Bamfords kartlegging, at skriveferdighetene bedrer seg når skrivestarterne er visuelle tekster. Yenawine forklarer det slik: 
As students' eyes scrutinize works of art, they find what interests them and search for words to express observations of all sorts - simple to complex - and the meanings, ideas, and emotions they draw from figures, interactions, settings, gestures, expressions, even colors. They find words to make subtle distinctions, language rarely employed day to day. As their ideas become more complicated, they are driven toward more complex vocabulary and sentences. (Yenawine, 2014, s. 106)

Yenawine konkluderer med at skolen i langt større grad bør la elevene få tid til å bruke sine tekstkunnskaper og videreutvikle muntlige og skriftlige ferdigheter ved å finne ord til å fortelle historier basert på visuelle inntrykk. Da lærer elevene å undersøke ukjent materiale, formulere sine egne ideer, lytte til andre og diskutere. Dette er ikke bare en måte å begynne å utvikle kritisk tenkning hos elevene på, men vil også kunne bidra i arbeidet med å lese og forstå skriftlige, skjønnlitterære tekster. Yenawines fremgangsmåte, visual thinking strategies, kan vi kanskje dermed best beskrive som en visuell lesemetode basert på en kunstfaglig tilnærming til metakognitivt arbeid og kritisk tenkning. Vi finner disse tankene igjen i overordnet del i Kunnskapsløftet, der det står at elevene skal kunne «bruke språk for å tenke, skape mening, kommunisere (...) [og] vurdere ulike kilder til kunnskap og tenke kritisk om hvordan kunnskap utvikles. (...) Danning skjer når elevene lærer hvordan de kommer fram til riktig svar, men også når de forstår at det ikke alltid finnes enkle fasitsvar» (Kunnskapsløftet, 2017, s. 165-168). Videre står det at det skjer dybdelæring og det utvikles viktig kompetanse når elevene tilegner seg og anvender faglige kunnskaper og ferdigheter på ulike måter og for å løse oppgaver i kjente og ukjente sammenhenger. Kunnskap om læringsstrategier og forståelse for egne læringsprosesser oppnås når elever «lærer å formulere spørsmål, søke svar og uttrykke sin forståelse på ulike måter» (Kunnskapsløftet, 2017, s. 170). Slik får vi elever som bygger kunnskap på en mer selvstendig måte.

Hvis man ser Pennes (2010) bekymring for elevenes mangel på forståelsesformer i møte med ikke-skjønnlitterære narrativer i lys av resultatene fra Bamfords (2008) kartlegging, Yenawines (2014) metoder og overordnet del i Kunnskapsløftet (2017), blir misforholdet mellom elevers kjennskap til skjønnlitteraturen og de andre mediene mindre alvorlig. Elevers forkunnskaper om populærkulturen og multimodale tekster kan ofte være et fortrinn når man skal få dem engasjert i arbeid med lese- og språkkompetanse i sammensatte grupper:

I dag hentar barn forteljingane sine frå langt fleire kjelder enn bøkene; i deira verd lever forteljingar fordomsfritt side om side i teiknefilm, teikneseriar, bøker og dataspel. Som med dei fleste vaksne har barn eit sterkt episk behov, og dei leitar opp forteljingane der dei er å finne. (...) Den forteljingskompetansen barn byggjer opp ved å sjå teiknefilm, tek dei eit par år seinare med seg over til dataspel og vanleg spillefilm. (Mjør et al., 2006, s. 219) 
At elevene lett blir engasjert i fiktive verdener i for eksempel filmer og ikke alltid klarer å skille mellom fantasifremstillinger og fremstillinger av fakta, nevnes ikke som et problem av lærerne i Bakkens undersøkelse. Men for at elevene skal kunne videreutvikle engasjementet som film skaper, kreves det at de øves i å skille mellom fantasi og virkelighet og gis tilgang til ord, begreper og lesestrategier som gjør dem i stand til å beskrive og reflektere over leseopplevelsen. Slik kan bruk av film bidra til at flere elever både kommer nærmere kompetansemålene i læreplanen («gi uttrykk for egne tanker og meninger» om engelskspråklige tekster) og oppnår en mer helhetlig tekstkompetanse i tråd med det utvidede literacy-begrepet.

\section{Sjangerlære som møtepunkt for skjønnlitteratur og fiksjonsfilm}

I likhet med Yenawine påpeker også Stafford at visuell lesekompetanse opprinnelig ligger til kunstfagene, og han understreker at det er nødvendig å forankre det i en språkfaglig sammenheng dersom vi ønsker at det skal bidra til å bedre elevenes engelskferdigheter (Stafford, 2011, s. 6). Her mener Stafford at skjæringspunktet mellom disiplinene er tydeligst i arbeidet med bilder som narrativer og i sjangerlære:

The concept of genre is a key part of literacy teaching and an understanding of it enables children to develop not only their own writing, but also their own critical and analytical reading skills. Genre is one of the many areas in which visually based texts can be linked to the teaching of the traditional written text so that children can concomitantly develop their knowledge of individual media and of genre itself. On a basic level, genre is a category or a type. Identifying which genre (or genres) a text belongs to is a means of understanding and classifying it based on its form and content while also relating it to existing texts. Considering how an individual text conforms or contravenes the traditional rules of its particular genre allows pupils to develop a specialized knowledge of both text and genre and encourages them to make connections between texts. (Stafford, 2011, s. 113)

Stafford baserer seg på McArthur’s (1972) ikonografi-teori når han skal beskrive hvordan filmer viser sjangertilhørighet. I følge McArthur følger en film innen en sjanger et spesielt mønster av visuelle uttrykk. Det vil alltid være noen gjenkjennelige objekter og karakterer som inngår i visse typer forhold, som hjelper seerne å identifisere hvilken sjanger den aktuelle filmen tilhører. Stafford (2011) forenkler McArthur's teori og fokuserer på tre kategorier alle elever vil kunne jobbe med uten å ha inngående kjennskap til filmen fra før: Karakterer, setting og rekvisitter. For eksempel ville mange elever kunne dra paralleller mellom kjente eventyr og filmsjangeren fantasy basert på sjangertrekk som karakterer i form av drager og monstre, middelaldermiljøer med borger og riddere samt spesielle objekter med magiske krefter. 
Stafford foreslår at lærere oppmuntrer elever til å knytte observasjoner til disse tre kategoriene, for eksempel ved å konsentrere seg om: "the facial expressions and emotional states of the people or animals in the images and considering what story the pictures might be telling” (Stafford, 2011, s. 23). En forutsetning for at elevene skal kunne forstå filmer som narrativer er at de tilegner seg nødvendig kunnskap om og språk til å beskrive grunnleggende teknikker og narrative virkemidler i film. Her vil også språklig svakere elever kunne begynne å jobbe med begreper som kameravinkel, lyssetting og fargebruk for å forklare hvordan filmen påvirker dem. Slik vil elevene etter hvert lære seg å sette ord på og forklare kjente og ukjente filmkonvensjoner, som for eksempel at nærbilder ofte blir brukt til å formidle følelser hos karakterer som ikke kommer frem i dialogen, eller at flere korte sekvenser etter hverandre kan bidra til en følelse av økt tempo og spenning. Også Penne (2010) peker mot en lignende tilnærming til litteratur og film gjennom sjangerlære, og hun trekker spesielt frem eventyrene: «I motsetning til konfliktene i litteraturen er konfliktene i filmen tydelige, og de driver handlingen fremover. Personene handler som følge av konfliktene, de møter motstand, de feiler og prøver igjen (...) Filmen har i større grad beholdt en tradisjonell og progressiv fortellingsstruktur, ikke så ulikt eventyret» (Penne, 2010, s. 194-195).

\section{Eventyret og fantasy-filmen - et eksempel på teorien i bruk i undervisningen}

Jeg avslutter her den generelle teoretiske drøftingen og vil i den videre teksten gi leseren et eksempel på en filmtekst vi kan bruke for å illustrere en slik tilnærming gjennom sjangerlære. Brave (Modig i norsk oversettelse) fra 2012, har klare referanser til det litterære eventyret og var Pixars første animasjonsfilm med en jente i hovedrollen. Språket er skotske dialekter, men filmen har relativt enkel dialog med desto mer handling. Samtidig er filmen tematisk kompleks nok til å kunne brukes på mellomtrinnet. Den tilhører fantasy-sjangeren, men tar også opp temaer som er typiske for drama, slik som konflikter mellom foreldre og barn, løsrivelse, ekteskap og kjønnsstereotypier. Handlingen er lagt til det skotske høylandet i tidlig middelalder og handler om den egenrådige arveprinsessen Merida, som virkelig får testet hva det innebærer å være «modig» når hun trosser skjebnen og setter politiske allianser og farens kongedømme på spill når hun nekter å gifte seg. Hun kommer i konflikt med moren og går til drastiske skritt, som å benytte seg av trolldom for å forvandle henne, slik at forlovelsen ikke kommer i stand. Magien utløser imidlertid en rekke problemer, som Merida selv må ta konsekvensene av og rydde opp i. Ikke minst innser hun etter hvert at hun trenger moren sin og søker forsoning med henne, noe som virkelig krever mot. 
Brave følger mønsteret Penne beskriver med et anslag, en åpningssekvens som raskt introduserer oss for sted, hovedpersoner og konflikter. For mindre språkkyndige elever er det lett å tolke visuelt de innledende scenene og relativt raskt forstå hva som kommer til å bli viktige elementer i historien og definere sjanger. Fortellingen begynner med et tilbakeblikk til da Merida var liten, og vi ser henne og moren leke i utkanten av en skog. Seerne får en klar oppfatning av at båndet mellom dem er sterkt og fylt av kjærlighet. Faren gir Merida en bue, noe moren tydelig misliker. Når Merida prøver buen, skyter hun pilen inn i den dype skogen. Når hun går for å lete, får hun hjelp av lyktemenn til å finne riktig vei tilbake igjen, før familien blir angrepet av demonbjørnen Mor’du. Så får vi en overgang til filmens nåtid, hvor Merida er i begynnelsen av tenårene. Overgangen består i en bilderekke av det skotske høylandet i skiftende årstider, noe som indikerer at vi forflytter oss i tid. Mens vi ser bilder av ikoniske kulturminner, som bautaer med piktiske inskripsjoner, introduserer en overstemme filmens hovedtema: «Some say our destiny is tied to the land. (...) It's the one thing we search for or fight to change. Some never find it. But there are some who are led». Vi får videre vite at faren klarte å forsvare familien, men at han ikke klarte å drepe bjørnen og at kampen dermed ikke er over.

Åpningssekvensen fungerer her som et frampek, der alt det tematisk viktigste blir presentert: faren gir Merida et middel (buen) til å utvikle ferdigheter som senere gjør henne i stand til å kreve frihet til å bestemme over eget liv. Moren frykter dette kan bli en vanskelig og farlig prosess, både politisk og for Merida personlig, og prøver å hindre det. Bjørnen kan tolkes som et symbol på kampen mellom plikten og familiens og samfunnets forventninger på den ene siden og individets ønske om å bestemme over eget liv på den andre. Mjør, Birkeland og Risa (2006) beskriver hvordan eventyrene ofte forteller om mennesker i overgangsperioder i livet, som for eksempel overgangen fra barndom til pubertet. Hans og Grete er et typisk eksempel på en slik fortelling, der hovedpersonene opplever å bli forlatt av foreldrene sine, for så å måtte ta egne valg og lære å klare seg i verden på egen hånd. Slike narsissisme - eventyr handler i psykoanalytisk teori om den frivillige eller den ufrivillige frigjøringen fra foreldrene. Men selv om den opprinnelige narsissistiske myten advarer mot overdreven selvdyrking, vektlegger eventyrene ofte betydningen av den sunne formen for narsissisme - den som fører til frigjøring og utvikling av et positivt selvbilde. Med Brave har man som lærer muligheten til å ta opp slike grunnleggende verdier og holdninger med elevene, som for eksempel at med selvrealisering og frihet følger også respekt for andres ønsker og behov, og at kommunikasjon er viktig for å løse problemer og misforståelser.

I Brave er begge formene for narsissisme del av selve hovedtemaet og formidles på et nivå gjennom en oversiktlig handling og gjenkjennelige konflikter for elevene. Samtidig bryter Brave med mange av de klassiske eventyrmønstrene og beveger seg over i fantasy-sjangeren, med mer sammensatte karakterer og med mer komplekse beskrivelser av verdier og 
budskap. For eksempel er faste elementer i eventyr ofte typer som har klare roller eller oppgaver og som enten motarbeider eller hjelper helten. Det kan også være egenskaper hos helten selv som kan arbeide for eller mot ham. Meridas mor, Elinor, er imidlertid hverken en typisk god, død mor eller en ond, levende stemor som forlater stebarna sine i skogen, slik som mødre ofte blir fremstilt i de klassiske eventyrene. Hun er en sammensatt person med reaksjonsmønstre lik en ekte tenåringsmor. Heksa i fortellingen er heller ikke entydig positiv til å gi Merida magien hun ber henne om. Det er Merida selv som ikke bare nekter å gifte seg, men som i en svært symbolsk handling kutter familiebildet som moren har vevd i to - og dermed splitter familien og støter moren fra seg. Her får vi en mer sammensatt fremstilling av den klassiske eventyrhelten, der heltens (narsissistiske) egenskaper arbeider mot henne på ett plan (i fortellingen om konflikten med moren), men for henne på et annet (i fortellingen om hennes kamp for selvstendighet).

I Brave er dessuten frigjøringsprosessen koblet til opprør mot tradisjonelle jente- og kvinneroller i eventyr. «I eventyra er ekteskapet symbolet på det mogne mennesket, som har frigjort seg frå foreldra (Mjør et al., 2006, s. 76), men i Brave er bruddet med moren et ledd i en kamp for å oppnå retten til å velge om man vil gifte seg, til å bli uavhengig og selvstendig: «I’ll be shooting for my own hand!» sier Merida når hun melder seg på i bueskytterkonkurransen for å vinne over beilerne sine. På denne måten kan man også lese Brave ikke bare som et moderne eventyr, men som en type anti-eventyr som gjør opprør mot og leker seg med konvensjonelle eventyrregler (Mjør et al., 2006, s. 72).

\section{Visuelle lese- og læringsstrategier i film - karakterer}

Brave egner seg godt til å inkludere alle elever i arbeid med grunnleggende leseog skriveferdigheter siden filmens temaer kan beskrives med et vokabular som mange elever allerede delvis behersker på engelsk og som de er kjent med fra lærebøker på lavere trinn. Det er hentet fra elevenes hverdag, som for eksempel mat, farger, tall, vær, årstider, høytider, familie, fritidsaktiviteter og hobbyer, kropp og klesplagg. Og selv om temaer er ulikt presentert og med ulik progresjon, vil de fleste lærebokverkene også ha gjennomgått eventyr og spøkelses- og spenningshistorier, med et vokabular som kan knyttes til spenningsopplevelser, sansene og handling. Uansett hvilket nivå elevene er på når det gjelder lesing i tradisjonell forstand, vil alle kunne bli oppmuntret til å ta i bruk både sin passive språkkunnskap og gloser i lærebøkene for å beskrive sine reaksjoner og tolkninger i arbeidet med Brave.

En førlesingsoppgave, i tråd med Yenawines (2014) metode for å få elevene til å lete etter narrativer, kan være å kopiere opp noen bilderuter fra en utvalgt sekvens og be elevene analysere kamerateknikker og karakterenes kroppsspråk for å foreslå hva ordvekslingen og konfliktene karakterene imellom kan dreie seg om og lage snakkebobler til hvert bilde. Språklig svakere elever vil kanskje synes det er lettere å lage en bildefortelling (picture story), der de skriver en kort 
tekst med utgangspunkt i bilderuter de velger selv. Vokabularet kan de også bruke til å forklare skriftlig hva de for eksempel har tegnet og illustrert i et tankekart (mind map) om karakterene i Brave. Tankekartet er et verktøy man kan bruke blant annet for å aktivisere bakgrunnskunnskap og beskrive karakterer og øve ord. Elevene kan ta for seg én eller flere av karakterene i Brave og tegne disse i en sirkel. Ut fra sirklene kan man tegne piler til engelske ord for kroppsdeler og klesplagg på karakteren man har tegnet. Her er det også differensieringsmuligheter, siden elever kan bygge ut tankekartet med adjektiver, for eksempel: brave girl, strong dad, strict mum. Svake elever kan ha behov for å bruke bildeordlister (picture dictionaries) i arbeidet med tankekartene, mens sterkere elever kanskje bare har behov for vanlige ordbøker.

Filmens tidsbegrensning gjør at karakterenes klesplagg og utseende ofte blir viktige for å formidle karaktertrekk som skjønnlitteraturen kan bruke lenger tid på å formidle. Stafford (2011) viser at ved å studere karakterenes fremtoning mer grundig, vil elevene få bedre innsikt i hvordan informasjon blir overført visuelt, og hvordan noe informasjon er eksplisitt, som i form av styrke gjennom kraftig kroppsbygning, eller implisitt gjennom en spesiell klesstil som elever kan tolke som tegn på karaktertrekk, men som ikke nødvendigvis blir oppfylt eller bekreftet gjennom handlingsmønstre i løpet av filmen. Stafford foreslår også en oppgave hvor elevene skal beskrive karakteren med et adjektiv; 'Cruel/haughty', for så å underbygge dette med visuelle bevis; 'Downturned mouth, cold eyes' (Stafford, 2011, s. 99). En litt større oppgave kan være å be elevene skrive et avsnitt, slik de forestiller seg den samme karakteren fremstilt i en roman. Tankekartene nevnt tidligere kan man også ta frem igjen etter at elevene har sett filmen ferdig, slik at de kan vurdere om det er noe de vil endre på eller legge til av karaktertrekk, alt etter hvor mye de ulike karakterene har utviklet seg i løpet av handlingen og basert på hvordan elevene vurderer de første egne tolkningene av åpningsscenene.

\section{Visuelle lese- og læringsstrategier i film - mise-en-scène og kinematografi}

Med Brave har vi muligheten til å trekke inn elevenes forkunnskaper om fantasy-sjangeren for å diskutere historie og hvilke assosiasjoner de har til kulturuttrykk i filmen. At Brave er en film i fantasy-sjangeren kommer tydelig frem i settingen; seerne blir presentert for en «historiemiks» av menn med både tartan-mønstrete kilter og vikinginspirerte klær, blå kroppsmaling assosiert med pikterne, keltiske smykker og kvinner i kjoler typisk for høymiddelalderen. En tidlig aktivitet for å gjøre elevene oppmerksomme på dette kan for eksempel være å stoppe filmen etter de innledende scenene og be elevene beskrive hva de ser. Vikingenes angrep blir nevnt i filmen som en av grunnene til at de fire klanene samlet seg og valgte Meridas far til konge, og her kan man se nærmere på historiske fakta om forholdet mellom Norge og Skottland og snakke om geografi, hvor vikingene seilte og hvor de kriget og slo seg ned på de britiske øyer. 
Kulturuttrykkene gir oss også anledning til å undersøke hva som er fantasielementer og hva som er realisme i filmen og å diskutere effekter av kinematografi og filmkunst. Ifølge Stafford (2011) er det viktig å gjøre elevene oppmerksomme på at de fleste filmscener er manipulert med tanke på å få frem en spesiell stemning, og i noen filmsjangre er dette mer påfallende. Typisk for nettopp fantasy og eventyr-sjangeren, er mytiske artefakter og stiliserte fremstillinger av landskap. Et eksempel i Brave er lyktemennene, som er et lysfenomen som kan oppleves i naturen i virkeligheten, men som i folketroen er overnaturlige skapninger som i filmen lett har latt seg adaptere. Noen elever vil kanskje også bli overrasket over at bautaene (standing stones) vi ser i Brave ikke først og fremst er et fantasy-element, men kulturminner fra virkeligheten.

\section{Visuelle lese- og læringsstrategier i film - fortellingsmønstre}

Det finnes også andre læringsstrategier man kan bruke for å aktivisere elevenes kunnskap om fortellingsmønstre og som gjør det enklere å sammenligne filmog litteratursjangre. Læreren kan for eksempel stoppe filmen og spørre elevene hva de tror vil skje videre. Da må elevene bruke fantasien samtidig som de må hente fram det de allerede vet om typiske eventyr- og fantasytrekk og fortellerteknikker. Selv om Brave har en relativt enkel og for det meste lineær struktur, kan elevene i denne sammenhengen ha behov for å få en oversikt over hendelsesforløp, konsekvensrekker og konflikter som bygger opp under filmens tema. En måte å få til dette på, er å la elevene gjenfortelle historien i en tidslinje. Lærere må vurdere hvor mange film- og analysebegreper man vil introdusere, men en måte å diskutere for eksempel vendepunkt og klimaks på, kan være å først be elevene beskrive hva de synes er den mest dramatiske eller spennende hendelsen i filmen. Hvis man deretter spør hva de mener er den viktigste hendelsen, vil mange elever hevde at disse er identiske. Her har vi en mulighet til å gjøre dem oppmerksomme på virkemidlene som blir brukt i film, hva en konflikt er og hvordan fortellingen er bygd opp rundt en eller flere konflikter. Læreren kan eventuelt først diskutere med elevene hvor på tidslinjen man skal plassere disse hendelsene og deretter la dem fylle ut gjennom å skrive og tegne hvilke andre hendelser de synes er viktige å ha med. Her vil også elevene lettere kunne se at handlingen i Brave styres av to konflikter. Man kan videre diskutere hva som kunne ha skjedd hvis Merida hadde gjort som moren ville, og sette opp alternative tidslinjer basert på en sammenligning av fortellingsmønsteret i fantasy-filmen med de vi finner i de tradisjonelle eventyrene.

\section{Konklusjon}

Når det gjelder effekten og fordelene av kunstfaglig tilnærming i andre fag, understreker Bamford (2008) at det er behov for mer longitudinal forskning (Bamford, 2008, s. 115). For engelskfagets del kan vi vanskelig få til dette hvis 
vi ikke integrerer kulturutrykk som fiksjonsfilm bedre og mer systematisk i undervisningen. Læreres positive holdninger til filmers læringsverdi er et godt utgangspunkt, men vi må også i større grad begynne å dokumentere resultater av undervisning basert på disse antagelsene.

Eksemplene fra Brave viser at det ligger mange muligheter i å ta i bruk film relativt tidlig i engelskundervisningen - utover det å gi elevene tilgang til autentiske engelske tekster og kulturuttrykk. Elevenes forkunnskaper, som de henter fra den rike verden av tekster og kultur- og kunstuttrykk de daglig befinner seg i, gjør dem i stand til å bidra i undervisningen og å lære både gjennom og om film. I et språklæringsperspektiv blir film her en del av den utvidede tekstkompetansen elever skal utvikle, hvor de også får et metaperspektiv på hvordan de kan jobbe for å tilegne seg filmteori og nyttige ord og begreper for å beskrive både filmnarrativer og skjønnlitterære narrativer. Slik kan elevene på sikt utvikle en mer helhetlig tekst- og lesekompetanse. Metodene beskrevet her illustrerer i tillegg hvordan en kunstfaglig tilnærming til arbeid med visuelle tekster og leseprosesser kan utløse en selvtillit hos elever som bidrar til at flere kan lære på en mer selvstendig måte og delta mer aktivt i undervisningen.

\section{Om forfatteren}

Britt W. Svenhard er tilknyttet engelskseksjonen ved avdeling for økonomi, språk og samfunnsfag ved Høgskolen i Østfold.

Institutional affiliation: Avdeling for økonomi, språk og samfunnsfag, Høgskolen i Østfold, Bra veien 4, Remmen, 1757 Halden

E-mail: britt.w.svenhard@hiof.no

\section{Referanser}

Andrews, M. (Regissør). (2012). Brave. USA: Disney - Pixar.

Bakken, A. S. (2016). When teachers talk about films: An investigation into some aspects of English teachers’ discursive practices. Acta Didactica, 10(1), 5. doi: 10.5617/adno.2513

Bamford, A. (2008). Wow-Faktoren. Globalt forskningskompendium, om kunstfagenes betydning i utdanning. Oslo: Musikk i skolen.

Cole, D. R. \& Pullen, D. L. (red.) (2010). Multiliteracies in Motion: Current Theory and Practice. New York: Routledge.

Flavell, J. H. (1979). Metacognition and Cognitive Monitoring: A New Area of CognitiveDevelopmental inquiry. American Psychologist, 34(10), 906-911.

Giorgis, C., Johnson, N. J., Bonomo, A., Colbert, C., Conner, A., Kauffman, G. \& Kulesza, D. (1999). Children's Books: Visual Literacy, The Reading Teacher, 53(2), 146-153.

Iwai, Y. (2011). The Effects of Metacognitive Reading Strategies: Pedagogical Implications for EFL/ESL Teachers. The Reading Matrix 11(2), 150-159. 
Keene, E. O. \& Zimmermann, S. (2013). Years Later, Comprehension Strategies Still at Work. The Reading Teacher, 66(8), 601-606.

Kjærnsli, M. \& Jensen, F. (red.) (2015). Stø kurs. Norske elevers kompetanse i naturfag, matematikk og lesing i PISA 2015. Oslo: Universitetsforlaget.

Kunnskapsdepartementet. (2017). Læreplanverket for Kunnskapsløftet. Grunnskolen. Oslo: Pedlex.

Lankshear, C. \& Knobel, M. (2011). New Literacies: Everyday Practices and Social Learning. Maidenhead: Open University Press. McGraw Hill Education.

Makin, L. \& Whitehead, M. (2004). How to Develop Children's Early Literacy. London: Paul Chapman Publishing.

McArthur, C. (1972). Underworld U.S.A. London: Secker and Warburg.

Mjør, I., Birkeland, T. \& Risa, G. (2006). Barnelitteratur - sjangrar og teksttypar. Oslo: Cappelen Akademisk Forlag.

Penne, S. (2010). Litteratur og film i klasserommet. Didaktikk for ungdomstrinnet og videregående skole. Oslo: Universitetsforlaget.

Stafford, T. (2011). Teaching Visual Literacy in the Primary Classroom. Comic books, Film, Television and Picture Narratives. New York: Routledge.

Yenawine, P. (2014). Visual Thinking Strategies. Using Art to Deepen Learning Across School Disciplines. Cambridge, MA: Harvard Education Press. 